\title{
THE SEARCH FOR HISTORY IN MIXTEC CODICES
}

\author{
Maarten Jansen \\ Rijksuniversiteit, Archeologisch Centrum, Postbus 9515, 2300 RA Leiden, the Netherlands
}

\begin{abstract}
This article begins with a historical review of the study of ancient Mixtec civilization and how codices became alienated from the Oaxaca region and culture. Current interpretations of codices' geographic reality, their religious dimension, and the problems of chronology are discussed. Accurate interpretation of the Mixtec codices is shown to be very much dependent on the collaboration of modern Mixtecs, as the inheritors of the ancient culture.
\end{abstract}

\section{HISTORICAL SURVEY}

During the viceroyal period the study of ancient Mixtec civilization was as neglected as the Mixtec region itself, which suffered through years of economic exploitation. Since the Mixteca was marginal to the colonial centers of New Spain, few Spanish authors bothered to describe Mixtec culture or history, and those who did usually presented their information in an indirect, incomplete, or even distorted way. This can be clearly seen in the earliest sources available to us. For example, crucial information on Mixtec religion must be extracted directly from an inquisition trial against nobles from Yanhuitlan (1544), and fragmentary but important data are to be found imbedded within the linguistic works of the Dominican friars Antonio de los Reyes and Francisco de Alvarado (1963/1593). In the seventeenth century another Dominican, Fray Francisco de Burgoa (1934/1674), wrote a baroque history of the "spiritual conquest" of Oaxaca, mixing his numerous references to the Mixtec world with biblical citations and elaborate praise of pious missionaries. More systematic, if limited and heterogeneous in detail, are the questionnaires known as the Relaciones Geográficas, written about 1580 (Acuña 1984) and intended to inform the Spanish King about his possessions and their prospects for colonial use. Drawing from these Relaciones, several of which are now lost, the official "Chronicler of the Indies," Antonio de Herrera y Tordesillas (1549-1625), wrote the first synthesis of Mixtec culture in his "Historia General de los Hechos de los Castellanos" (1947). ${ }^{1}$

An exception to such sources is the partial and condensed transcription of a now lost Mixtec literary work dealing with cosmology and sacred history; this was published by the Dominican friar Gregorio García (1981) in his rather confused

'A "classic" synthesis of these sources is Dahlgren (1954). A general survey of Mixtec society can also be found in the important studies of Ronald Spores $(1967,1984)$. Other works by Spores $(1972,1974 a)$ focus on the archaeology of the Nochixtlan Valley. For more information on archaeology see Flannery and Marcus (1983), Lind (1979), Ramsey (1982). Different aspects of the colonial history of the region were treated recently by Pastor (1987) and Romero Frizzi (1976, 1985). Interesting descriptions of Mixtec culture by Mixtecs in our own century appear in Dyk (1959) and Schultze Jena (1938). recompilation of sources on the origin of Native American peoples. The opening lines of Garcia's synthesis succeed in conveying some impression of the epic dimension of the original and recall the style of the Quiche Maya Popol Vuh:

\begin{abstract}
In the year and on the day of darkness and mist, before there were days or years, when the world was in great obscurity and everything was chaos and confusion, the earth was covered with water. Only mud and slime were on the face of the earth. In those days appeared visibly a God, named 1 Deer "Lion-Serpent" and a gentle and beautiful Goddess, named 1 Deer "Jaguar-Serpent." These two deities, they say, were the beginning of the other Gods. After appearing visibly in the world, in human shape, they made and founded in their omnipotence and wisdom a huge rock, on which they constructed with great skill luxurious palaces, their seat and abode on the earth. On top of the house and dwelling of these Gods there was a copper axe, the edge turned upwards, on which the sky rested. This rock and these palaces of the Gods were on a very high mountain, near the town of Apoala, in the Province called Mixteca Alta. In the language of this people the rock was called Place where Heaven was. (García 1981:327-328)
\end{abstract}

In early sources Mixtec pictorial screenfolds are mentioned several times, but not commented upon in detail. During the century following the Spanish invasion, the pictographic tradition slowly became extinct in the Mixtec region, partly because of the destructive zeal of Christian missionaries and partly because of replacement by alphabetic writing. The documents that survived were either looted or taken out of the country by foreigners who wanted curiosities for their collections or, more rarely, were stored in local archives. Those that left the area often became disassociated from their origins.

Several Mixtec codices figured prominently among the early Mexican items ending up in European art collections and libraries. The book on the origins of the Mixtec Lords and the genealogical history of Tilantongo, now known as the Codex Vindobonensis Mexicanus 1, for example, was in Europe by 1521 , and thereafter experienced a turbulent and peripatetic history. It wandered from the royal court of Portugal to the Vati- 
can, where a young cardinal eventually inherited it from Pope Clement VII. This cardinal, a member of the Medici family, soon succumbed to poison, however, and the codex was solicited from his legacy by a German Bishop, then serving as counsellor to the Pope. After the latter's death, the humanist scholar Widmanstetter, secretary to the bishop, took the codex to Germany. After some years the screenfold was bought by Duke Albrecht V of Bavaria for his Art Chamber. During the Thirty Years' War the Bavarian capital, Munich, was conquered by the Swedish king (1632), and the Ducal Art Chamber was plundered. The codex then came into the possession of the Duke of Sachsen-Weimar, whose descendant eventually (around 1677) presented it as a diplomatic gift to the Emperor of Austria. ${ }^{2}$ Thus, the document became the "Codex Vienna," or in Latin, "Vindobonensis," totally divorced from its ancient Mixtec context and, therefore, quite incomprehensible to its new owners.

Other codices suffered similar fates. Even in this century spectacular manuscripts have left the Mixtec region, often in circuitous and illegal ways. An example of this is the roll reportedly stolen from the church of San Martín Huamelulpan in the beginning of this century by Samuel Daza, a local painter. Daza's family then sold the roll to the resident of Oaxaca, $\mathrm{Fe}$ lix Muro, a Spanish merchant known to have purchased other important items of ancient Mixtec art, such as the codex of San Pedro Cántaros (the "Codex Muro") that is now in the Mexican National Museum of Anthropology. Eventually, Muro sold the Huamelulpan roll, which was subsequently smuggled out of Mexico, wrapped in ladies' underwear. In 1932 it was acquired by Tulane University in New Orleans, where it is now termed "Codex Tulane." 3

It is indicative of such vicissitudes that most codices now have quite un-Mixtec names and designations. These labels are symbolic of the historic alienation of the Mixtecs (and indigenous peoples in general) from those who study their heritage and who generally belong to another, dominant ethnic group. Native Americans often feel this alienation as painful proof of a persistent colonial structure. Few scholars recognize how offensive such names and terms can be to indigenous peoples.

By the second half of the sixteenth century the Mixtecs had substituted alphabetic writing, both in the Mixtec language and in Spanish, for codex painting. Only a minor number of such Mixtec texts have survived, particularly in a few local archives, such as the Archivo del Juzgado de Tepozcolula and the Archivo General de la Nación (Josserand, Jansen, and Romero

${ }^{2}$ The history of the Codex Vindobonensis Mexicanus 1 was discussed in detail by Adelhofer (1974), Lehmann and Smital (1929), and was completed by Toorians $(1983,1984)$. For the art chambers in general see Nowotny (1960) and Scheicher (1979); for their background and related concepts see, among others, Kohl and Schmid (1982) and Lemaire (1986).

${ }^{3}$ The history of the roll has been traced by Ross Parmenter in a still unpublished article, "The Acquisition of the Codex Tulane," and by Alejandro Mendez Aquino (1985:282). A gloss written on the roll further refers to the town of San Juan Numi, neighbor of Huamelulpan. Studies of the contents by Mary Elizabeth Smith show that it must have originated in yet another town, probably in the Mixteca Baja (see Robertson 1982a). Its style and iconography show similarities with those of the Codex Dehesa and the Mapa de Xochitepec. On the other hand, its opening section mentions personages who also occur in the Codex Vindobonensis Obverse (page 4) and, as names of Holy Bundles, in the Lienzo de Zacatepec. Moreover, the central section depicts several individuals from the Teozacualco dynasty (cf. page 29 of the Codex Nuttall).
1984); unfortunately, these texts have not received much scholarly attention. In Republican times schools began to combat use of indigenous languages through their program of a new spiritual conquest, called "castellanization," "modernization," and "national integration," so that it has become less and less common to write in Mixtec. To counter this trend, Native American movements have tried to create a consciousness of the cultural and linguistic heritage of their peoples, as well as to work towards social justice (e.g., APIBAC 1980; Garduño Cervantes 1983). This conflict is already palpable in the first original studies of Mixtec culture, published in Oaxaca at the end of the nineteenth century. With political independence from Spain, a gradual but persistent interest in the precolonial past began to develop among the new élite in Mexico, especially among politicians, scholars, and teachers.

The complex and badly known history of Mixtecs, Mixes, Zapotecs, and the other peoples of Oaxaca-the state of the first Native American president Benito Juárez - has been extracted from its fragmentary viceroyal sources by local historians such as Juan B. Carriedo (1949/1847) and José Antonio Gay (1978/1881). It was Manuel Martínez Gracida (18471923), however, who first undertook to enrich these insufficient data through broader inquiries. He published an impressive and highly detailed geographical description of all settlements in the state (Martínez Gracida 1883) and collected many historical notes and observations on Indian cultures, including drawings and descriptions of archaeological sites, oral traditions, toponyms, and their etymologies in the native languages. He also saw and studied a number of original codices and other antiquities, several of which were acquired by him for public institutions. Yet it proved difficult to interpret these finds. Scholarly understanding of pictographic conventions was then in its infancy, and a survey of all relevant sources was impossible because of their dispersion and lack of editions. In his ambitious project to reconstruct the precolonial past of Oaxacan peoples, Martinez Gracida resorted to intuition and imagination. By this means he produced evocative accounts of dynasties, rulers, battles, speeches, heroic deeds, and love, with the principal aim of raising the historical and cultural consciousness, patriotic idealism, and virtues of his contemporaries. ${ }^{4}$ It should be emphasized that Martínez Gracida did not present these accounts as scientific studies but rather as novelistic legends and traditions.

One of Martínez Gracida's collaborators was Mariano López Ruiz (1872-1931). López Ruiz was a native of the Mixtec region. He was apparently born in Tilantongo, but lived and worked most of his life in Nochixtlan. He was responsible for several of the descriptions of Mixtec sites and antiquities in Martínez Gracida's work. In 1887, following earlier explorations by the local priest Juan Tomás Palacios in 1882, López Ruiz conducted excavations in the ceremonial center of Tilantongo, where he discovered:

aqueducts, fragments of fountains, concave slabs, mutilated pieces of columns, fragments of the facades of buildings, and several triangular stones, all of solid cantera, of rose-colored marble with beautiful red veins, many with incrustations apparently of gold-others with hardly recognizable figures

${ }^{4}$ Many of these accounts were never published, but remain as manuscripts in the state library in Oaxaca city. A selection of the plates was published in 1986. For more information see Brioso y Candiani (1910), Jansen (1987), and Parmenter (1982). 
of animals and plants, showing decorations and hieroglyphic inscriptions. ... (Martínez Gracida, unpublished works)

López Ruiz was a poet (Silva Fuentes 1988) and co-authored with Martínez Gracida the novel Ita Andehui (1906). He also had access to a now lost Mixtec pictorial manuscript containing a number of Mixtec glosses, of which he published an interpretative reading in 1898 . Even though this reading contains a great number of inconsistencies and confusions, it was an important venture at the time, showing that the codices could actually be read as historical narratives.

A third figure of importance to early interpretations of Mixtec codices, and one who wrote from the same educational and emancipatory perspective in a lyrical, poetic style, was the well known Mixtec teacher Abraham Castellanos (1868-1918), also from Nochixtlan. Using a highly intuitive reading of the Codex Colombino (published by the Junta Colombina in 1892), he created the literary legend of Iukano (Fischer and Durr 1988; Jansen 1987). The toponymic glosses were read as narrative texts, and the images were interpreted not just as historical accounts but as the myth of a wandering Mixtec king and a mystical manifesto of the cyclical struggle of the Mixtec people. Castellanos' work was written on the eve of the Mexican Revolution and is an authentic example of Mixtec resistance literature:

\footnotetext{
They promised you liberty, but after the victory you don't even have the most basic rights. "It is just an Indian," the oppressors say, and the Indian passes by, with his soul in pain. They promised you prosperity, and the caciques keep exploiting your work. "After all, it is only an Indian," the caciques say, and the indian passes by, with his soul in pain. Having seen your misery, I spoke to our common Mother, I spoke to the mountain, so that mankind may hear me, and I repeat it here: "The indians groan and ask for help, nobody has reached out a saving hand to them; they fell into their misfortune four hundred years ago, and they live because they are strong, because they are patient and valiant, because they were taught so by the good God. Wake up, Mother Ixtaccihuatl, and take care of your children. . . !" But you too, wake up, my brothers! (Castellanos 1910:86)
}

Even though interpretations of pictographic details and scenes have evolved considerably since then - few of the specific readings by Martínez Gracida, López Ruiz, and Castellanos would be regarded as valid today - such pioneers deserve credit for being the first to identify Mixtec codices as such and to recognize their historical contents, Mixtec concepts, literary style, and educational value. In doing so, they were guided by a profound knowledge of the geography and traditional culture of the region, and their intuition was reinforced by their direct collaboration and personal identification with the people concerned.

At the same time, a separate tradition of scholarship evolved far distant from the Mixtec region, taking as its point of departure the codices preserved as treasures in European libraries and museums. Various scholars undertook the difficult work of editing the codices and writing commentaries of them. For example, in his wish to demonstrate that the Native American peoples originated in the 10 lost tribes of Israel, Lord Kingsborough published (between 1831 and 1848) a great number of ancient Mexican manuscripts, among them the Bodley, Selden, and Vindobonensis codices; he did not provide commentaries. In 1902, Zelia Nuttall published the codex that ever since has carried her name. In a pioneering introduction she analyzed the document as an historical text but she did not relate it to Mixtec culture, linking it instead to the Aztecs. In utter contrast to Nuttall's view was the interpretation proposed by her contemporary, the German scholar Eduard Seler, the founder of modern studies of ancient Mexican iconography. Seler saw these codices, which he called "Vindobonensis Group," as religious documents similar to the Borgia Group. Furthermore, in conformity with the general view of the time, he analyzed myths and religious iconography as the symbolic representations of the movements of sun and moon, planets and stars. ${ }^{5}$

Both Seler and Nuttall had their followers, the former mainly among German-speaking scholars, the latter mainly among English-speaking ones. Whereas Kreichgauer, Lehmann, and Rock elaborated Seler's astrological interpretation, Clark, Long, and Spinden explored clusters of scenes that made sense as historical narratives. For none of them, however, was the Vindobonensis Group surely Mixtec. That discovery had to await the publication of a classic article by the Mexican archaeologist and ethnohistorian Alfonso Caso (1949), who demonstrated that a sequence of individuals in the Vindobonensis Group was identical with genealogies painted on the Map of Teozacualco, a Mixtec pictorial document which accompanies the 1580 Relación Geográfica of that town. The genealogies on the Map were glossed as those of the rulers of Tilantongo and Teozacualco, the main cacicazgos in the Mixteca Alta. Caso's article conclusively established that these codices were Mixtec historical documents. As such they were related to other documents of the region, such as the early colonial Codex of Yanhuitlan, published and extensively studied by Wigberto Jiménez Moreno and Salvador Mateos Higuera (1940). At the same time the fundamental work of Karl Anton Nowotny $(1948,1961 a)$, showed that "astralistic" or astronomical interpretations of myth and ritual in both the Mixtec codices and the Borgia Group had become obsolete.

Caso (1977-1979) later wrote commentaries on several Mixtec codices, as well as an impressive synthesis of Mixtec history and historical personalities, published posthumously. In these studies he analyzed the complex of genealogies and dates, offering detailed explanations of the pictographic scenes and proposing a correlation of the Mixtec historical chronology with Christian dates. According to his calculations, Mixtec history started as far back as the end of the seventh century A.D. Later investigators were able to modify and correct many of Caso's interpretations. Some studies focused on the identification of placename hieroglyphs (Jansen 1982b; Jansen and Pérez 1983; Konig 1979, 1984; Parmenter 1982; Smith 1973a, 1979, 1988), on the precise analysis of style and pictographic conventions (Robertson 1982b; Troike 1974, 1979, 1980, 1982a, 1982b) or on the problems of chronology and correlation (Aróstegui, per-

${ }^{5}$ It is interesting to note that Eduard Seler and his wife Caecilie Seler-Sachs travelled throughout the Mixtec region, visiting among other towns Tilantongo in 1895, where they collected antiquities. An account was given by Seler in his Gesammelte Abhandlungen, vol. II (19601961 ) and by Seler-Sachs (1900). For a biography of Seler, see Anders (1967). For a summarizing discussion of Seler's "Astraldeutung" in the Mexican codices, see Loo (1988). Although the astronomical paradigm has become obsolete by now (Dorson 1955), elements of this doctrine and attempts to relate pictographic scenes to occult astronomy can still be found in several recent publications, including Séjourné (1981). See also Parmenter (1988). 
sonal communication; Rabin 1981, 1982); others concentrated on the relationships between historiography, religion, ideology, and politics (Byland and Pohl 1989; Furst 1978b, 1982, 1986, 1987; Jansen 1985, 1988b; Jansen and Pérez 1983; Monaghan 1990; Pohl 1984; Spores 1974b, 1984).

Caso's publications, together with Nowotny's, formulated a paradigm for Mixtec codex research that is still essentially valid today. ${ }^{6}$ Strangely enough, this paradigm was developed separately from the work done half a century earlier by local historians in Oaxaca. It established the Mixtec origin of this group of codices in a strictly historical way, limiting its references to the above-mentioned chronicles and archival sources, yet it hardly took into account the living Mixtec culture or involved the Mixtecs themselves. In my opinion, this is a great weakness: the participation of the living Mixtec is crucial for a better understanding of their heritage.

\section{GEOGRAPHIC REALITY}

Having established that the "Vindobonensis Group" consisted of Mixtec codices, Caso succeeded in identifying several placename hieroglyphs for towns in the Mixtec area. The Teozacualco Map provided many important examples including a black-colored frieze representing Ñu tnuu, 'Black Town', the Mixtec name for Santiago Tilantongo. This place sign is accompanied by the picture of a temple decorated with the "heaven" motif, representing the "Temple of Heaven" (Huahi Andevui) which the Relación Geográfica de Tilantongo tells us was situated there. From this place came the dynasty which at a certain moment provided a ruler for the neighboring town from which the map comes, San Pedro Teozacualco. Its Mixtec name, Chiyo cahnu, means 'Big Altar'. To represent this name the Mixtec painter resorted to a phonetic word-play: cahnu, 'big', is rendered by using its homonym (with other tones) cahnu, 'breaking'. Teozacualco's hieroglyph thus is a frieze (ñu, town, place, people) that is broken. The small man breaking the frieze is not a specific individual, but only a sign expressing the action (Figure 1).

The study of Mixtec placenames and their hieroglyphic signs demands a grasp not only of Mixtec geography but of Mixtec language and belief, especially the way in which the Mixtecs conceive of their land. ${ }^{7}$ Because of tonal punning, dialect variety, and the historical development of Mixtec it may be extremely difficult to assess the etymology and translation of a specific placename. Most ancient Mixtec towns have a Nahuatl name too, which may coincide with the Mixtec name, or have a markedly different significance.

An interesting example is the sign for Zahuatlan (Figure 2) in the Codex Selden (Smith 1983). Zahuatlan means 'Place of Smallpox' or 'Place of Itching' in Nahuatl. Its Mixtec name is Yucu cata, which can mean several things: Yucu signifies 'mountain' but also 'herb', and cata refers to 'itching'. Thus, the

${ }^{6}$ Caso's posthumous Reyes y Reinos de la Mixteca $(1977-1979)$ is a useful synopsis. See also the studies by Glass (1975), Glass and Robertson (1975), and for later progress reviews, Gutiérrez Solana (1987) and Troike (1978). For general introductions to Mexican pictography, see Anders and Jansen (1988) and Jansen (1988a).

${ }^{7}$ Mixtec is a tonal language, part of the so-called MacroOtomanguean family. For a general overview of dialect variety, see Josserand (1983). Introductions to the grammar may be found in Alexander (1980), Dyk and Stoudt (1973), Ortíz Lopez (1982), and Pérez (1988).

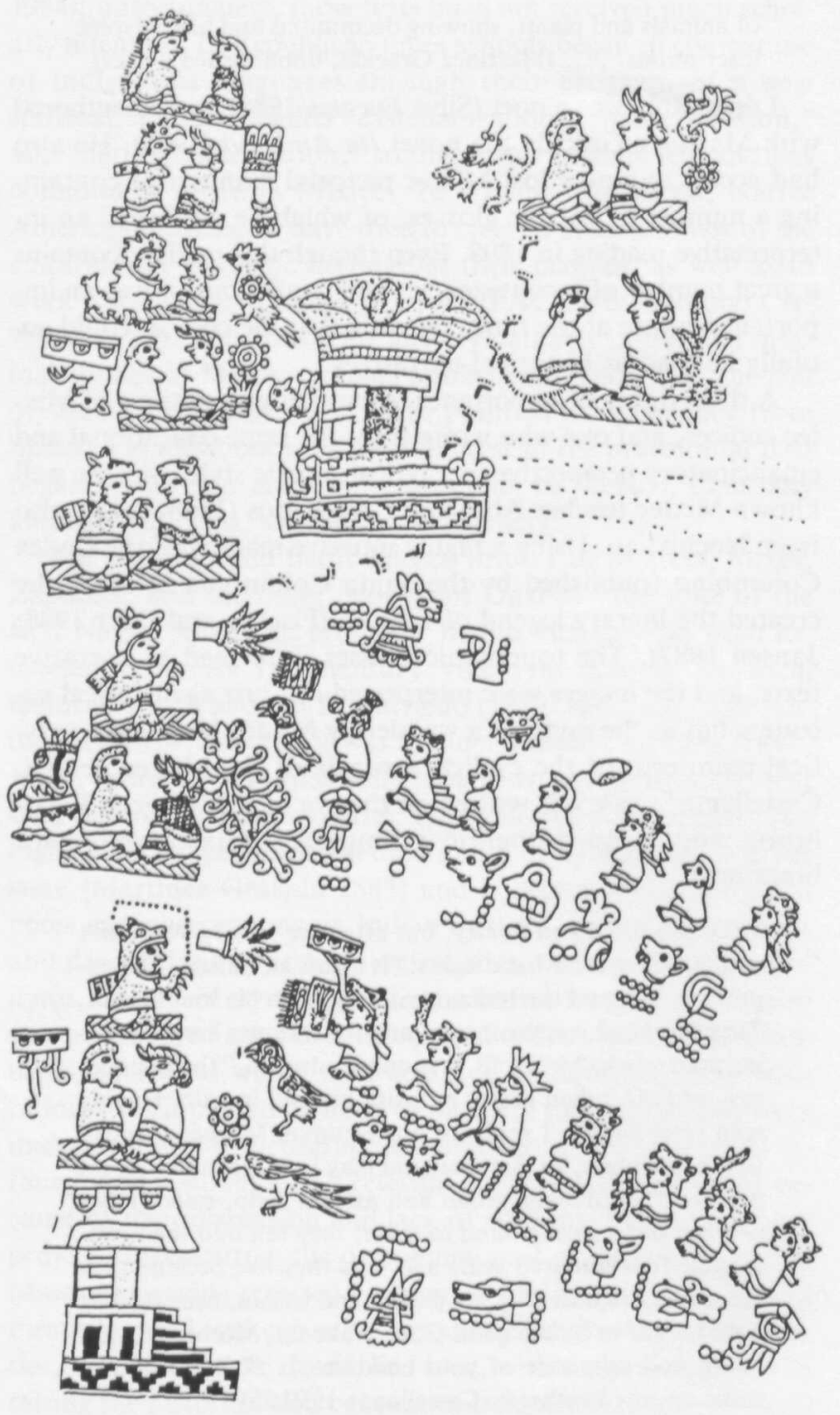

Figure 1. The place signs of Tilantongo and Teozacualco, from the Mapa de Teozacualco.

name can be understood as 'itching herb' or 'herb which cures itching'. Yet cata is also 'dancing', a meaning which may imply a notion of 'itching feet'. Indeed, the Mixtec toponymic sign is: 'Mountain of the Dancer' (observations by the Taller de Lectura de Codices Mixtecos, Oaxaca 1989). Such toponyms are of exceptional relevance to the interpretation of the codices, since they permit us to relate pictographic scenes to events recorded in other sources, usually from the viceroyal period. Thus, another identification by Caso, that of the 'River with the Hand Holding Feathers' as Yuta tnoho, 'River that plucks or pulls out', or Santiago Apoala (Smith 1973a:75), has made it possible to interpret the central theme of the Codex Vindobonensis Obverse and several sections of other codices in terms of Mixtec traditions that situate the origin of various royal dynasties in that town (Figure 3). According to a myth recorded by Fray Antonio de los Reyes and Fray Francisco de Burgoa, the first lords and ladies had been born from trees at Apoala (Furst 1977, 1978a; Jansen 1982b). 


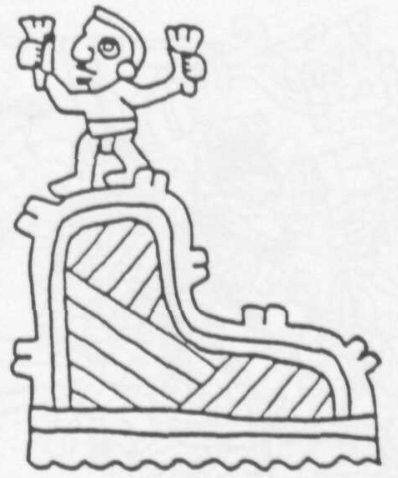

Figure 2. The place sign of Yuca cata, page 11 of the Codex Selden.

In the Codex Vindobonensis Obverse the founding fathers make their way from Apoala, from the Tree of Origin, to different places in the Mixtec region. Among the latter references to the four cardinal points can be found, as registered in the dictionary of Fray Francisco de Alvarado: Heaven (East), Dark Mountain (North), River of Ashes (West) and Temple of Death (South). These glyphs, therefore, represent a special theme that occurs not only in several Mixtec codices, but also in Cuicatec and Chocho documents (Jansen 1982b).

\section{RELIGIOUS DIMENSIONS}

Ancient Mixtec history is a holy history, as Abraham Castellanos had already sensed, not only because of the abundance of deities and rituals, but because of the exalted status of Mixtec ruling families (Pohl 1984). They shared with gods the general titles of iya, 'Lord', and iyadzehe, 'Lady', terms which clearly referred to personages of a divine character, and which today are generally applied to both Mixtec and Christian deities. The dynasties had sacred ancestry: according to several Relaciones Geográficas and codices, the founding fathers had been born from trees or stones, or from heaven or earth. In the codices they sometimes arose or came out of the place signs themselves; occasionally they are associated with plants, possibly in metaphorical allusion to their close connection with the land (Figure 4). ${ }^{8}$ They may also be depicted as Bearers of the Holy Bundle (called yya sandidzo by Fray Antonio de los Reyes), the bringers of the doctrines and laws, who took possession of the Mixtec area. As such they may be compared with the Aztec teomama (Eschmann 1976).

Apoala was the most important place of origin. From there the first lords and ladies dispersed in the four directions, giving names to the lands, building temples, and celebrating the New Fire ceremonies, as in the Codex Vindobonensis Obverse.

\footnotetext{
${ }^{8}$ Such concepts still play an important part in modern Native American ideology: "We are a natural part of the earth. We are an extension of the earth; we are not separate from it. We are part of it. The earth is our mother. The earth is spirit, and we are an extension of that spirit. We are spirit. We are power. They want us to believe that we have to believe in them, that we have to assume these consumer identities and these political identities, these religious identities and these racial identities. They want to separate us from our power. They want to separate us from who we are. Genocide" (John Trudell, in Churchill 19881989:ii).
}

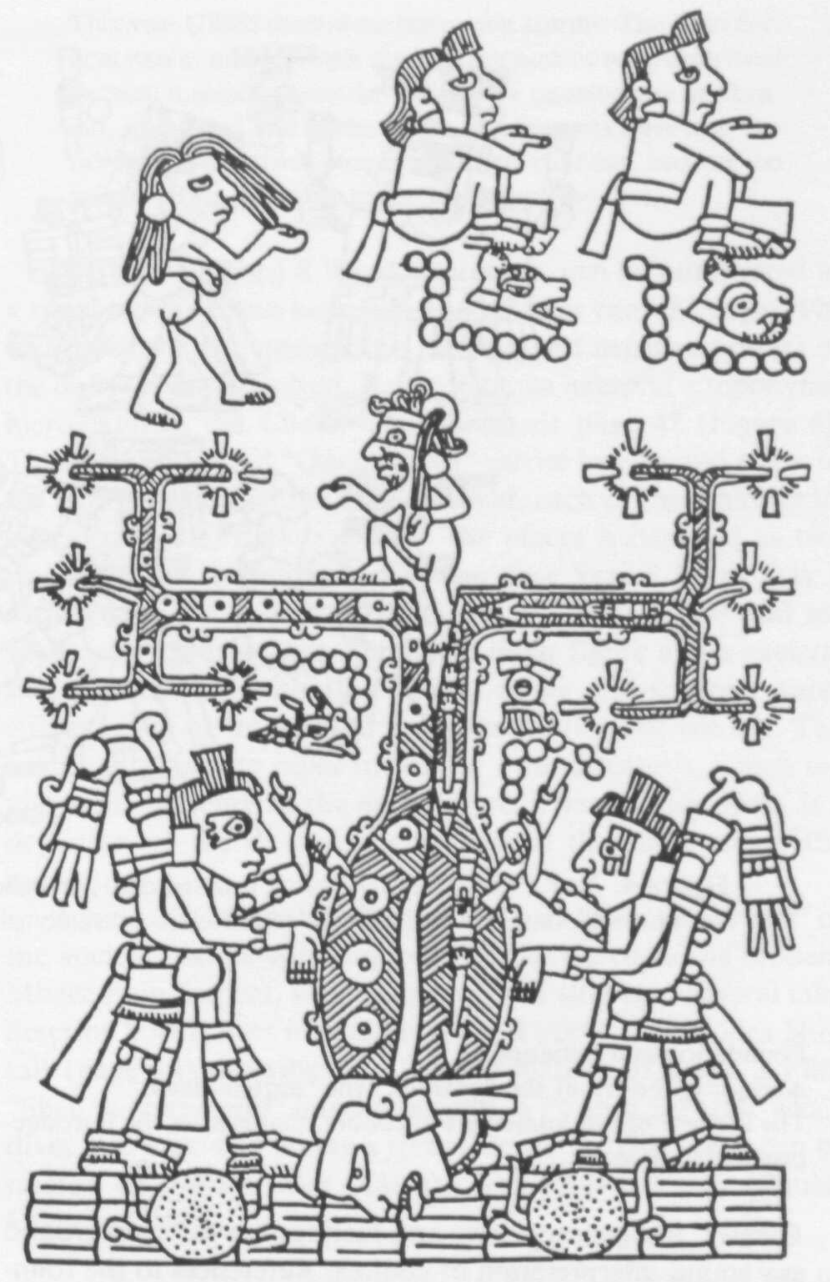

Figure 3. The Tree of Origin (Codex Vindobonensis, page 37).

The foundation of the cacicazgos was associated with sacred origins, with the four world directions, with cults, ceremonial dates in nondurational time, and the mythical story of the war with the Stone Men, depicted in the Codex Nuttall (pages 34,20 ). The Stone Men appeared as a primordial people, similar to those who, according to modern Mixtec tales, withdrew into caves and chasms or turned into stone when the sun rose for the first time (Dyk 1959:17; Jansen 1982b). References to such a primordial people are also given by Antonio de los Reyes (1976) in his prologue, where he describes them as tay nuhu, 'men of the abysm', who had come forth from the center of the earth and had lived in the region long before the Lords of Apoala. History in these codices, obviously, is Mixtec history: events and ideological statements are conceptualized and represented in Mixtec terms and according to the ancient Mixtec world-view. This explains the numerous parallels between the historical descriptive codices and the prescriptive (divinatory and ritual) Codex Borgia group. Today, Mixtecs distinguish between different historical periods, which clearly coincide with precolonial thought (observations by the Taller de Lectura de Códices Mixtecos, Oaxaca 1989):

1. The primordial time of darkness, when giants lived, and strange and divine beings ( $\tilde{n} u h u$ 's) turned to stone at the first sunrise. 


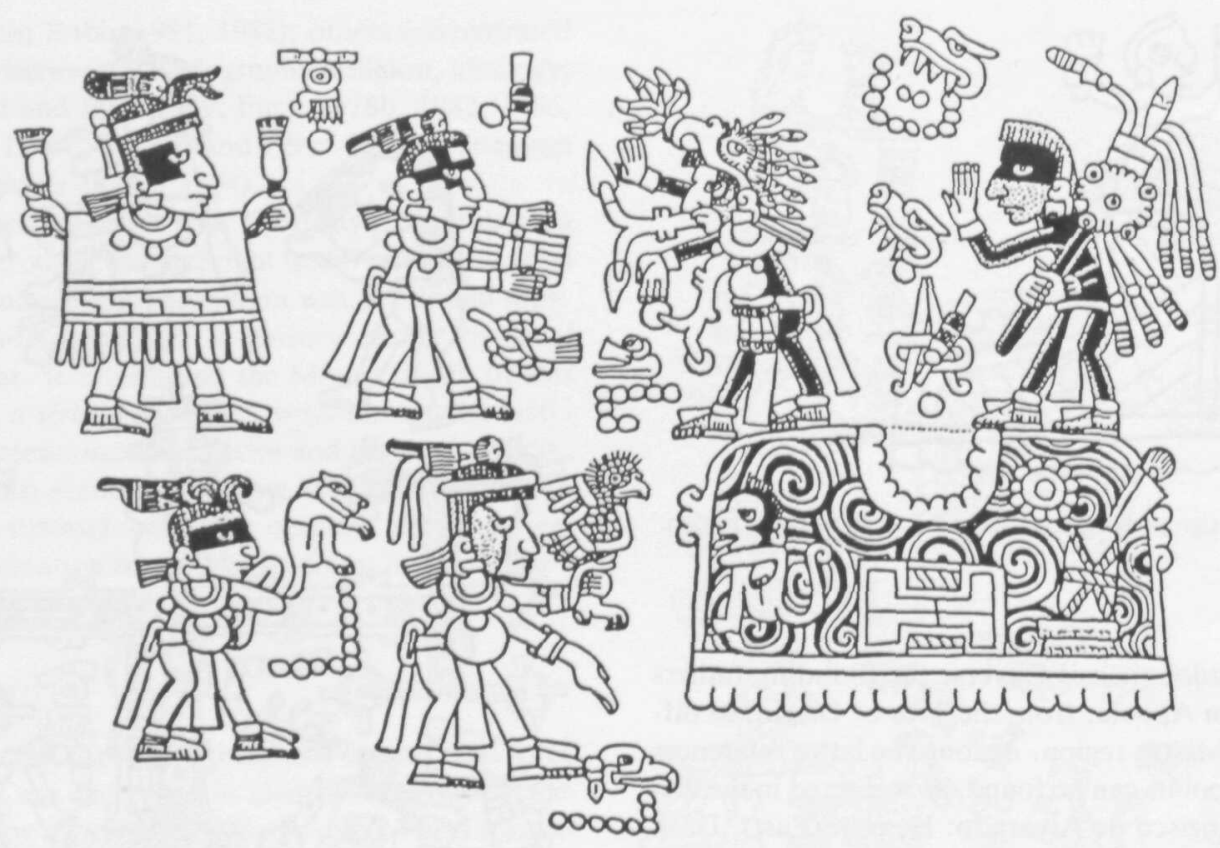

Figure 4. Year 1 Reed, Day 1 Alligator, a sacred date that indicates "beginning." Lord 8 Wind, identified with various plants, comes out of the Mountain of the Monkey and receives a ceremonial greeting (Codex Nuttall, page 1).

2. Foundation and initiation.

3. Antiquity, the era of the "gentiles," the "ancient dead."

4. The lifetime of our immediate ancestors, that is after the introduction of Christianity.

Clearly, indigenous views and feelings are the background to any sound interpretation of codices. References to the foundation of the kingdoms and dynasties not only state the historical provenance of lineages, but also provide legitimation by relating them to the primordial ordering of time and space. This is the dominant theme of Codex Vindobonensis Obverse and of the "early sections" in several other codices. Some, including the Vindobonensis and the Selden Roll, stress the sacred and ritual aspect of the foundation period, as well as the primordial instructions and works of Lord 9 Wind "Quetzalcoatl," the birth from the Tree, the New Fire ceremonies, among other events. Others, such as the Codex Nuttall, speak of a primordial struggle, a conflict between the primeval Stone People and the Lords from Apoala. ${ }^{9}$ In the following period, a new order is created by the impact of historical acts of influential personages such as Lord 8 Deer "Jaguar Claw," whose spectacular rise to power, alliances and conquests affected a large part of the Mixtec re-

${ }^{9}$ With this frame of reference it is possible to interpret the war against the Stone Men (Codex Nuttall, pages 3-4, 20) as a mythical struggle preceding the actual founding of the dynasties (Rabin 1979; Smith 1973b:71). The representation in the Nuttall is ambiguous, especially in view of its difficult chronology, which rests on dates that seem to be non-durational in character (Jansen 1988b). In my view, the Stone people attack the First Mixtec Lords (many of whom appear in the Codex Vindobonensis Obverse associated with the Tree of Origin at Apoala), but finally are defeated by them. The capturing or sacrifice of a Stone Man seems to be equivalent to taking possession of a cacicazgo, an event indicated elsewhere by New Fire ceremonies or by the simple combination of the Founding Fathers with a ceremonial date and a place sign. gion. Later generations also referred to such deeds as a legitimation for their own claims. Furthermore, we find a continuous interaction of historical personages with divine powers, in accordance with the indigenous view of individuals being part of nature and subordinated to nature's superior forces. Humans meet with deities in ritual or in personal visionary experiences. Humans may also represent deities, particularly when they are dedicated to such supernaturals (Hvidtveldt 1959; López Austin 1973). Another direct relationship is the dream-experience of the tonal or nahual, a separate identity of man in nature, expressed as an animal or other being, that determines his character and fate but also enables him to encounter and experience divine powers. ${ }^{10}$

Many details in the codices, which at first do not call our attention, may include references to the spiritual world of Mesoamerican peoples. This world is very much alive today, transformed but also enriched rather than destroyed by Christian beliefs. Since these complex ideas are incompletely mentioned and badly understood by Colonial sources, our interpretation of the codices is very much dependent on the collaboration of modern Mixtecs, who are the inheritors of that ancient culture.

An example is the scene (page 5) of the Codex Nuttall in which Lord 8 Wind "Twenty Eagles," before his marriage and accession to the throne of Suchixtlan, is bathed by the Rain God, who comes down from heaven in a burning flash of lightning, pouring water out of a vessel onto the sitting lord (Fig-

${ }^{10}$ The experience of having one or more "animal doubles" (alter egos) is widespread in Mesoamerica and among the Mixtecs in particular (López Austin 1980:416-432). Kohler (1985) discussed the phenomenon in relation to Olmec iconography. Similarly, López Ruiz 1898:442) interpreted the animal attire of individuals in a Mixtec codex as signs of "nahualistic practices." For other studies that focus on Mixtec spiritual world, see Casas et al. (1987), Ibach (1980, 1981), Krumbach (1982), Mak (1959), Monaghan (1990), Paw (1951). 


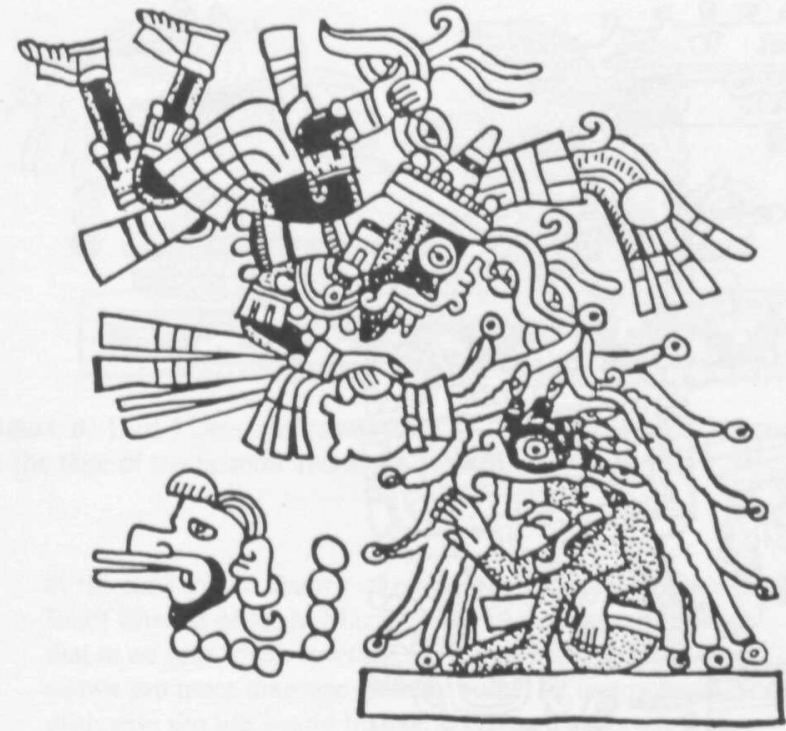

Figure 5. Lord 8 Wind bathed by the Rain God (Codex Nuttall, page 5).

ure 5). The scene in itself is clear, but the following comment (written in the Mixtec of Chalcatongo) places it in its Mixtec context:

Shraan vaha ja kuchiyo nducha sau nuu kanduuyo shi tahanyo kuehe ñuhu ini.

Tana nducha sau ja koho shi ja kuchi ñayiu katahan kuehe nuhu ini. Kanindiiyo in kisi-yujuehe te sakuaha na too nducha sau uan te suana kuchiyo nducha sau uan chi tana. Kayoo ñayiu ja kanduu koo sau, tikacha sau, koo tikacha ichi, taja, tachi sau, viko nuhu. Nuu kee nihi tachi sau te iin viko chi indee koo shi kuahan ichi uan. Te nuu kuahan koo sau kandua yunu, tahnu vehe, tahnu itu, kuahan nducha ñuhu, shraan kanduchitu yucha te tuka kakuu kajaha ñayiu ichi siki-yucha nuu chuha chi katene ñayiu, kittï, ndihikuankoyo nuu nducha yucha uan.

Kuia nikiiyo vina shraan nikuun sau shraan jiin tachi sau ni kii koo sau te shraan nikajihi ñayiu, nikatanu vehe ja nikuun sau shraan. Shraan niyoo nundoho ichi Yucatan, Nundua, ichi ninu (Norte), nisnaa arroz, nduchi jiin ndihi-ja nikajitu ñayiu uan chi nikii kiti-indee ini nducha kahnu. ${ }^{11}$

It is very good to take a bath with rain water, especially if we transform ourselves [that is have nahual experiences] or if our tono ('alter ego') has become ill. The water of the rain is medicine to those who have an illness of the tono (tonal), they should drink it or bathe in it. A vessel is put at the door to catch the rain water, so that we may bathe in this water, which is medicine. There are those who turn into Rain Serpents, rain whirlwinds, serpents of dry whirlwinds, lightning, rain winds, haze. When there is a strong wind, when there are clouds it is because the Serpent is there or has passed through. Where the Rain Serpent goes trees fall down, houses and fields are destroyed, floods occur, the rivers swell so that people cannot get across them. The river carries them away: People and animals, all disappear in the water of the river.

\footnotetext{
${ }^{11}$ Mixtec text and related codex interpretations: Gabina Aurora Pérez (personal communication, 1988).
}

This year (1988) there were many rain storms: The Rain Serpent came, many people died, many houses were destroyed because it rained so much. There were catastrophes in Yuca$\tan$, in Oaxaca and in the North, the harvests were lost, the rice and beans which people over there cultivate, because the animal came that lives in the big water (the sea).

The bath of Lord 8 Wind, therefore, can be interpreted as a ritual to strengthen both him and his alter ego, the eagle. The text illustrates the tremendous positive and negative powers of the divine beings involved. It also helps us interpret a toponymic hieroglyph in the Codex Vindobonensis page 47 (Figure 6). There, Lord 9 Wind "Quetzalcoatl" carries heaven and water to the various places of the Mixtec world, each of them having its own ceremonial date. ${ }^{12}$ One of the places is depicted as two water streams accompanied by the date Year 5 Flint, Day 8 Movement. The upper water stream has huge waves and sea shells; the lower stream contains a ñuhu figure and a skeletal saurian monster with flint knives in its claws. Both water streams may be interpreted as representations of the sea. The sea is called nduta $\tilde{n} u h u$ in Mixtec (' $\tilde{n} u h u$ water'), which explains the presence of the $\tilde{n} u h u$ figure. The monster, then, is a depiction of the death-bringing animal that lives there, the hurricane.

It is equally clear that Quetzalcoatl, or 'Plumed Serpent' of the ancient Nahua-speaking peoples, is related to the modern Mixtec Rain Serpent, which is a powerful alter ego. Several tales describe how it lives in small lakes and pools. The Codex Nuttall (page 14) describes the transformation of Lady 3 Flint "Shell quechquemitl" into her nahual, a Plumed Serpent, which dives into a cave to create a river (Figure 7). This scene can be related to similar tales that are well known today (Paulat Legorreta 1969).

\section{THE CHRONOLOGY PROBLEM}

The historical depth of the Mixtec codices is a question that is intimately related to the overall interpretation of genealogies and events. In the opinion of Martínez Gracida and López Ruiz, for example, the Tilantongo dynasty began in Toltec times (Jansen 1987). With this intuitive notion they were well ahead of their time. Zelia Nuttall thought that the codex named after her dealt with a period shortly before the Spanish invasion. The first thorough computation of a sequence of Mixtec dates was made by Richard Long, who analyzed the Codex Nuttall. His basic assumption is still valid:

\begin{abstract}
Now, as the dates in the Codex are given by the calendarround method, a year of the same name, such as 7 Acatl, will recur every 52 years. When such a date is followed by another, such as 10 Acatl, we know that it must either be 16 years (plus any number of calendar rounds) after 7 Acatl, or 36 years plus any number of calendar rounds) before it, and if we merely had the dates without any context we would get no further. But the Codex treats for many consecutive pages
\end{abstract}

\footnotetext{
${ }^{12}$ For a detailed discussion of Vindobonensis page 47, see Jansen (1988b). The action of Lord 9 Wind can be seen as equivalent to the New Fire ceremonies which occur at the same places later in the codex. Vindobonensis tells us how these places got their water and their New Fire, their seasons and their cults, their names and dates, in short how the cacicazgos were founded ceremonially and conceptually. See also Nicholson (1978).
} 


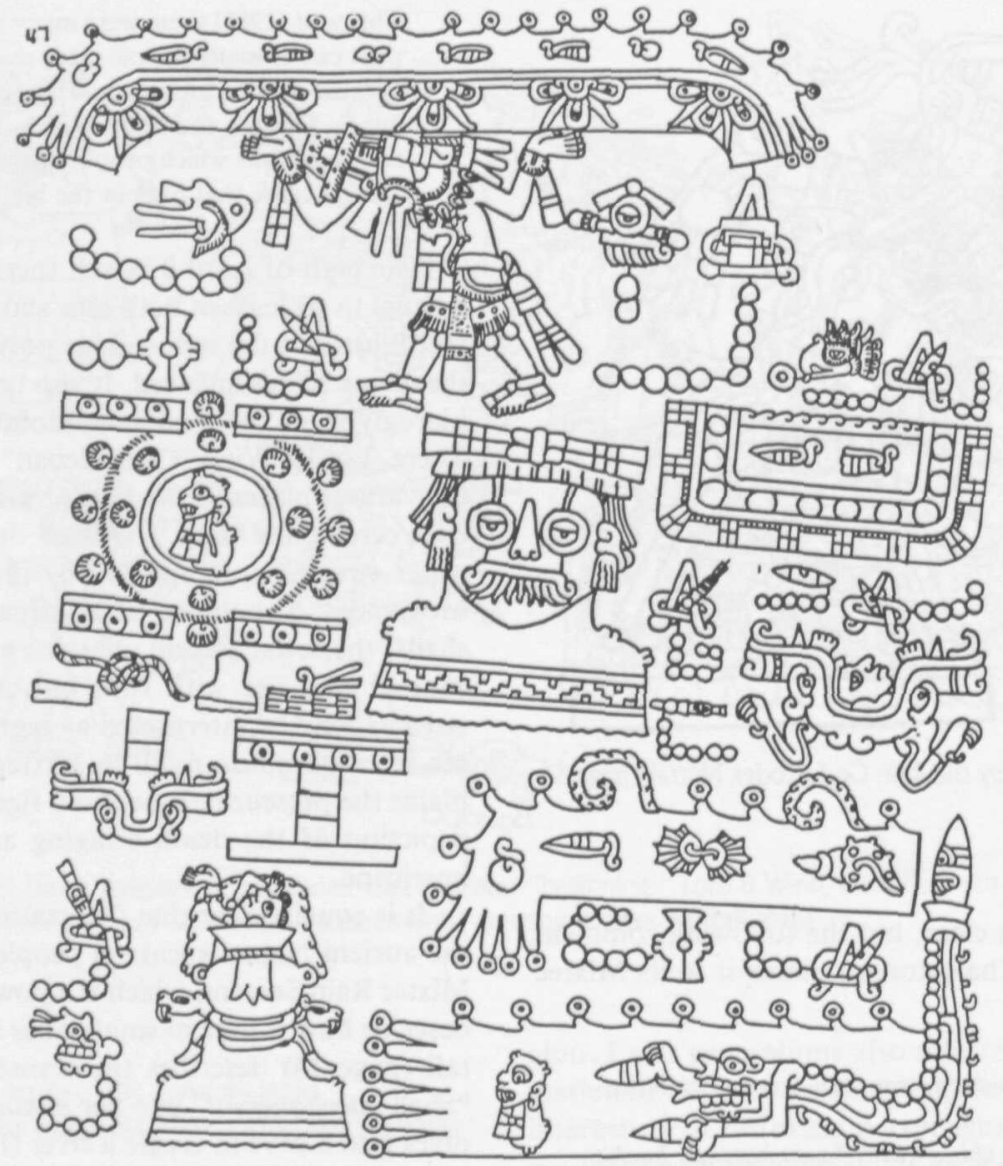

Figure 6. Lord 9 Wind "Quetzal coatl" brings water to the world (Codex Vindobonensis, p. 47).



Figure 7. After giving birth to a daughter, Lady 3 Flint becomes a Plumed Serpent and disappears into a cave (Codex Nuttall, page 4). 


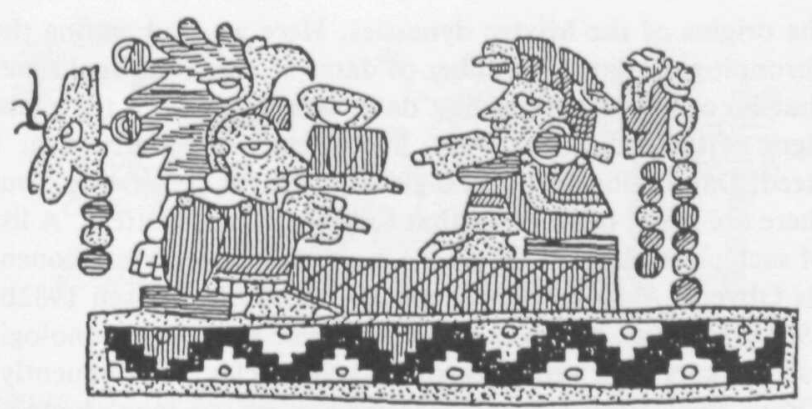

Figure 8. Lord 4 Deer and his wife Lady 11 Serpent, who ruled Tilantongo at the time of the Spanish invasion (Codex Bodley, page 19).

at the time of the history of particular individuals, such as Eight Ehecatl or Eight Mazatl. This at once gives the check that in no case where events in the life of the same person are shown can more than one calendar round be interpolated, as otherwise the life would be over a century long, while generally there could not be any calendar round intervening, and it gives the further check that while in most cases the count is forward from the last date, yet sometimes it must be backwards, when a forward count would give an unreasonably long distance. (Long 1926:240)

By taking the whole codex as a true historical record, Long calculated a total of approximately 610 years of precolonial history.

The Map of Teozacualco enabled Alfonso Caso to elaborate a much more complete and detailed overview of Mixtec historiography. Crucial to his reckoning was the knowledge of how the Mixtec counted their years in relation to the Aztec system: a Mixtec year 1 Reed roughly corresponded to an Aztec year 2 Reed, and so on (Jiménez Moreno and Mateos Higuera 1940). By calculating the sequence of dates in the genealogical framework, Caso proposed a new chronology, according to which the earliest dates in Mixtec history were in the seventh century A.D. Caso's firm base was the observation that some of the last generations of the Mixtec precolonial dynasties depicted in the codices were also mentioned in early colonial Spanish sources. For example, Lord 4 Deer of Tilantongo, depicted in the Codex Bodley (page 19-IV and 19-III), as well as in the Codex Selden (p. 18-IV), is mentioned in the Relación Geográfica of that town as Ya qh quaa (Nahui Mazatzin in Nahuatl), who lived at the time of the Spanish invasion but died shortly thereafter, without baptism (Figure 8). According to the Codex Bodley, Lord 4 Deer was born after his sister, Lady 5 Monkey, who was born in the Year 12 Rabbit. This Mixtec year had to be equivalent to A.D. 1466, since a date either 52 years earlier or later contradicts the Relación Geográfica. A younger brother of this Lord 4 Deer was Lord 8 Death (Namahu), who married Lady 1 Flower (Cahuaco). This pair appears as a ruling couple in Yanhuitlan in the beginning of the sixteenth century, both in Codex Bodley (page 19-III) and according to testimonies at a trial held at a later date (Archivo General de la Nación Civil 516; Spores 1967:132). In the same text, the father of Namahu has also been identified: Lord 10 Rain (Xico) of Tilantongo, who appears in the Codex Bodley (pages 18-I and 20-II). He was born in the Year 9 Flint, which can be correlated with A.D. 1424. The youngest sister of Lord 10 Rain, Lady 9 Deer was married to Lord 8 Grass of Tlaxiaco, that is, "Lord Malinalli," who, according to Torquemada, fought both Moctezumas. This Lord 8 Grass was born in the Year 7 Reed (Bodley, page 21-III), which has to be A.D. 1435 (Jiménez Moreno, in Gaxiola and Jansen 1978).

Starting from these dates Caso calculated well back into the past. Major problems remained however. Caso himself stated this explicitly:

\begin{abstract}
I warn, however, that the correlation between the two calendars (Mixtec and Christian), which I have proposed, is by no means indisputable, especially where early times are concerned. We may say that the correlation is reasonably valid for the fifteenth and sixteenth centuries, and naturally for the more recent periods, but that it may need correction by 52 and even 104 years. For more remote periods our correlation is merely tentative. (Caso 1977-1979:I:39)
\end{abstract}

As a result, Caso's chronology has been a topic of much debate and correction. Most specialists today accept the revisions proposed by Emily Rabin (1981), who has made a comprehensive analysis of the problem. For the sake of this discussion we may distinguish two main periods in Mixtec historiography: (a) the period between the lifetime of Lord 8 Deer "Jaguar Claw" and the Spanish conquest and (b) the period before Lord 8 Deer "Jaguar Claw," that is, the period in which the cacicazgos were founded and the first generations of lords and ladies ruled. For the period between Lord 8 Deer and the Spanish conquest, the dates are relatively clear. Caso's analysis follows the dates given in the codices and as such is impeccable. Yet there are some problems regarding the dates themselves. According to the Codex Bodley, pages 17-19, Lord 10 Rain (Xico) of the Tilantongo dynasty was born in a Year 9 Flint (Caso: A.D. 1424) and had his first child at the age of 42, in the Year 12 Rabbit (Caso: A.D. 1466), which, although not at all impossible, is late in terms of Mixtec custom. Lord 10 Rain's father was Lord 5 Flower, born in the Year 10 Rabbit (Caso: A.D. 1386), again a rather long generation span. The grandfather of Lord 10 Rain was Lord 6 Deer: he was born in a Year 7 House (Caso: A.D. 1357) and married a princess from Jaltepec.

The parallel sequence in the Jaltepec dynasty (Codex Selden, pages 14-17) is as follows: Lord 10 Monkey was born in the Year 2 Reed (Caso: A.D. 1339). His eldest sister married Lord 6 Deer from Tilantongo. The next of his sisters married Lord 8 Eagle. Lord 10 Monkey himself got married in the Year 12 Rabbit (Caso: A.D. 1362). His first child, Lord 3 Death, was born in the Year 2 Reed, which in Caso's sequence would normally be in A.D. 1391, but which should be corrected since it is very unlikely for a child to be born nearly 30 years after his parents' marriage. Lord 3 Death married the daughter of Lord 8 Eagle in the Year 5 Flint (Caso: A.D. 1368), which also fails to fit the sequence.

A son, Lord 1 Monkey, was born in the Year 1 Flint (Caso: A.D. 1416), again far too long after the marriage of his parents. Lord 3 Death fought a battle against his father-in-law Lord 8 Eagle in front of Jaltepec in the Year 9 Flint, A.D. 1424 according to Caso. This is a very late date for the lifespan of Lord 8 Eagle, who-again according to Caso's calculations - had married a princess born somewhat after A.D. 1339. Lord 1 Monkey in turn married a daughter of Lord 4 Flower of Tilantongo in the Year 6 Reed (Caso: A.D. 1447), shortly after, in the Year 8 


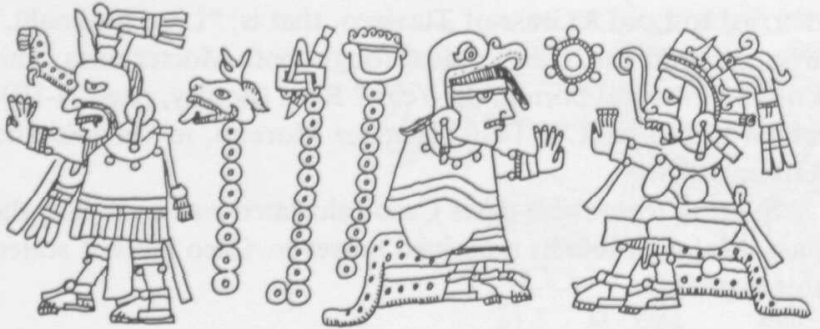

Figure 9. Lord 8 Deer, born in the Year 12 Reed, as first son of Lord 5 Alligator "Rain Sun" and Lady 11 Water "Precious Bird" (Codex Vindobonensis, Reverse page VII).

House (Caso: A.D. 1449) defended Jaltepec against Lord 3 Monkey "Jaguar of the Mexicans." Here Caso's dating is in accordance with the probable identification of this Lord 3 Monkey with "Tres Micos," cacique of Yanhuitlan, who, according to Herrera (Decade III, Book 3, Chapter 13) fought the Aztec invaders, and was betrayed and killed at the time of Moctezuma I (A.D. 1440-1469). Yet, this Lord 3 Monkey "Jaguar of the Mexicans" seems to have been identical with the person of that name who got married to a sister of Lord 6 Deer of Tilantongo (Bodley, page 17-II). It is inconsistent chronologically to fight battles around A.D. 1449 and to marry a wife born shortly after A.D. 1357.

Emily Rabin (1981) has suggested that in this sequence of dates an error must somewhere have crept in, involving one 52 year cycle too many. Rabin's hypothesis is supported by the possible connections with Central Mexican and Zapotec data (Jansen 1989; see also La Cruz 1983).

Lord 9 Lizard "the Mexican" of Jaltepec and Lord 9 House "Jaguar of the Mexicans" of Tilantongo seem to have participated in wars in the southern part of the present State of Puebla at the time of the Mixtec and Chocho expedition to Cuauhtinchan (Lienzo de Tlapiltepec, Selden, page 12). According to Caso's chronology the dates associated with these individuals' activities must refer to the first half of the fourteenth century. Dating these events one 52-year cycle later, to follow Rabin's hypothesis, fits better with Central Mexican chronology. Further back into the past, Lord 2 Dog was the offspring of a marriage between a Mixtec princess and a Zapotec lord (Nuttall, pages 33-34). It is possible that this marriage is the one that, according to the Relaciones Geográficas of Zaachila and Cuilapan, took place somewhat before A.D. 1280 (Jansen 1982a, 1989). If this is the case, the Year 10 House, in which Lord 2 Dog and his wife took possession of the cacicazgo of Teozacualco (Caso 1949), must correspond to A.D. 1321. Again, this would be 52 years later than Caso calculated (19771979:II:235). And if we follow Rabin's (1981) reasoning, the dates corresponding to the life of Lord 8 Deer "Jaguar Claw" would change from A.D. 1011-1063, as calculated by Caso, to one cycle later, A.D. 1063-1115 (Figure 9).

For the period immediately following Lord 8 Deer we lack a number of crucial dates. As a consequence, one could argue that yet another cycle should be removed so that Lord 8 Deer would have lived a 52-year cycle later (A.D. 1115-1167). Yet, this would imply extremely short generation spans of precisely 13 years for several generations, which seems unlikely.

The period preceding Lord 8 Deer "Jaguar Claw" is that of the origins of the Mixtec dynasties. Here we find among the chronological dates a number of dates in nondurational time, that is, ceremonial founding dates associated with the place signs of the cacicazgos. Caso had already discovered Year 1 Reed, Day 1 Alligator to be a general date for "beginning," but there are many other dates that follow a similar pattern. A list of such place/date combinations is given in Codex Vindobonensis Obverse, pages 47-38 (Furst 1978a, 1978c; Jansen 1982b, 1988b). ${ }^{13}$ Caso, however calculated these dates as chronological markers in a sequence of 52-year cycles. Consequently, Caso's correlation-sequence became a much too long, containing a number of inconsistencies and biological impossibilities.

An example is the following sequence of three generations: Lady 1 Death, her daughter Lady 1 Eagle/Vulture, and her granddaughter Lady 5 Reed. For the marriage date of Lady 1 Death Caso calculated A.D. 732, and for the birth of Lady 5 Reed's first son A.D. 888 (Vindobonensis Reverse, page I-3 and page IV-1, Caso 1977-1979:II:145, 301). This involves a 156year span for two women to be born, to mature, and to have children, which is contrary to natural patterns. A second example is the life of Lord 8 Wind "Twenty Eagles," founder of the Suchixtlan dynasty, who is mentioned in several different codices. Caso (1977-1979:II:58) dated his birth to A.D. 779 and calculated his daughter's marriage as A.D. 1038, which is equally impossible. As a solution Caso was forced to postulate the existence of two separate individuals of the same name, married to the same wife, but living in different epochs. In this part of the chronology, then, Emily Rabin's revision of Caso's correlations, is far more extensive, leading to dramatic modifications of our understanding of the ancient Mixtec.

Let us examine another complex example of Mixtec history: Lord 8 Deer "Jaguar Claw" was married to among others Lady 10 Vulture. Their marriage took place in the Year 2 House (A.D. 1105 according to the revised chronology). She was the daughter of Lady 7 Reed "Jewel Flower," who was the sister of Lord 12 Lizard "Arrow Legs" and the youngest child of Lord 10 Flower and Lady 2 Serpent (Bodley, pages 12-V, 5-IV, 5/6-V). This latter couple married in the Year 1 House, which now can be calculated as A.D. 1013. It should be mentioned here that in the Year 3 Flint (A.D. 1080) Lord 8 Deer "Jaguar Claw" visited the elder sister of his future mother-in-law Lady 7 Reed, and their sister was Lady 4 Rabbit, who at that time was already married (Bodley, pages 9-V and 6-IV).

Lord 8 Deer's father, Lord 5 Alligator "Rain-Sun," was a high priest in Tilantongo, and son of Lady 1 Vulture "Skirt of the Rain God," who belonged to the Tamazola dynasty (Codex Nuttall, page 23). This Lady 1 Vulture's brother, Lord 10 Reed, had married a daughter of the above-mentioned Lord 10 Flower and Lady 2 Serpent. The two daughters of Lord 10 Reed married their mother's brother, Lord 12 Lizard "Arrow Legs," another child of Lord 10 Flower and Lady 2 Serpent. Lord 5 Alligator, therefore, was a cousin (Mixtec: kuaha, 'brother') of the wives of Lord 12 Lizard "Arrow Legs."

The implications of these intricate family relationships are

\footnotetext{
${ }^{13}$ Several attempts have been made to relate these dates in nondurational time to astral phenomena or to various poorly understood sections of ancient Mesoamerican and especially Toltec chronology. These studies are highly speculative and unconvincing and include Brotherston (1983, 1985), Burland (1955), Corona Nuñez (1967), Hochleitner and Paula de Paula (1987), Kreichgauer (1917), Lehmann and Smital (1929), Melgarejo Vivanco (1980), Spinden (1940).
} 


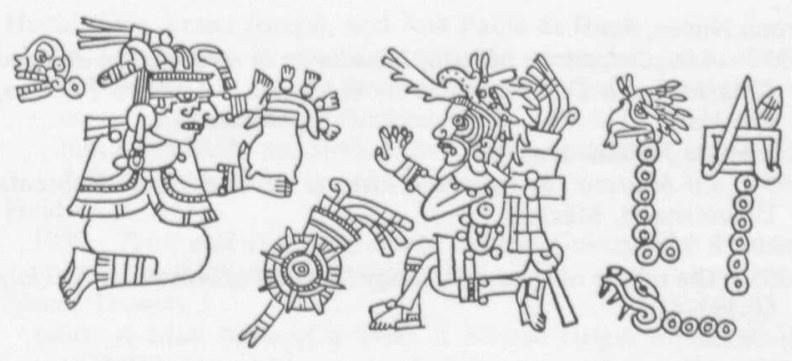

Figure 10. The marriage of Lord 4 Alligator and Lady 1 Death (Codex Vindobonensis, Reverse page I).

that Lord 5 Alligator cannot have been the successor of Lord 2 Rain "Ocoñaña," the grandson of Lord 12 Lizard "Arrow Legs" and last descendant of the "first Tilantongo dynasty," but in fact must have died 14 years before the death of Lord 2 Rain. It was Lord 5 Alligator's son, Lord 8 Deer "Jaguar Claw" himself, who, shortly after Lord 2 Rain "Ocoñaña” died, seized power in Tilantongo (Jansen 1982b; Rabin 1981).

Once it is established that the Year 1 House in which Lord 10 Flower married Lady 2 Serpent corresponded to A.D. 1013, then the birth year of Lord 10 Flower, the Year 6 Flint, has to be A.D. 992 . He was the son of Lady 5 Reed and Lord 9 Wind
"Stone Skull," who had married in the Year 4 Rabbit (A.D. 990). Lady 5 Reed was one of the three daughters of Lady 1 Eagle/Vulture "Precious Haze," who in her turn was the daughter of Lady 1 Death and Lord 4 Alligator (Figure 10). The most probable correlation for the date of the marriage of Lady 1 Death and Lord 4 Alligator, Year 6 Flint Day 7 Eagle, therefore is A.D. 940 (Codex Vindobonenis Reverse page I-IV).

A different line of reasoning yields the same results. According to Codex Bodley page 35-III, Lord 8 Deer's elder half-sister, Lady 6 Lizard, married Lord 11 Wind "Bloody Jaguar" in the Year 10 House (A.D. 1060). This Lord 11 Wind, who must have been born in the beginning of the 11th Century A.D., was the son of Lady 4/5 Jaguar, a sister of the just mentioned Lady 5 Reed and a granddaughter of Lady 1 Death. This also is an argument for dating Lady 1 Death's marriage to A.D. 940 .

Necessarily, the discussion of the chronology problem is technical and complex. It illustrates the many difficulties in the long search for history and historical facts in the ancient sources. In pursuing the meaning of pictographic details, we saw that this search has moved away from the inheritors of the investigated culture, the Mixtecs themselves. A slow but certain change has in this respect become visible, however, and the inevitable encounter of Americanist scholarship with Native American reality may have important consequences for future studies of the Mixtec.

\section{SUMARIO}

La búsqueda de una historia auténtica mixteca ha sido larga, empezando con la obra de los eruditos del siglo dieciséis, como Antonio de los Reyes y Francisco de Alvarado, y continuando a través del siglo diecisiete con las observaciones de Gregorio García y Francisco de Burgoa. Durante aquel período, los códices mixtecos se incorporaron a las bibliotecas de Europa, donde se les asignaron nombres poco apropiados y se les dieron atribuciones erróneas. Sin embargo, la erudición moderna empieza escencialmente con la Independencia mexicana, cuando se desarolló un interés en el pasado precolonial entre la nueva élite mexicana y entre los intelectuales oaxaqueños, como José Antonio Gay, Manuel Martínez Gracida, Mariano López Rúiz, y Abraham Castellanos, algunos de los cuales eran de origen mixteca. Otra tradición de análisis erudita, que tomó como punto de partida los códices preservados en Europa, se incorporó al final del siglo, cuando Zelia Nuttall y, aun más importante,
Eduard Seler, empezaron su investigación del pensamiento precolombino. Un acercamiento más histórico se desarrolló más tarde, con la obra de Alfonso Caso, quien mostró conclusivamente que varios códices, antes tomados por mexicanos, eran de hecho de origen mixteca. Este descubrimiento permitió que otros aplicaran su conocimiento de documentos coloniales a los manuscritos mixtecos precolombinos, lo que ha llevado a la firme identificación de topónimos y a un conocimiento más profundo de la religión, la ideología, la política, y particularmente la historia mixtecos, ahora comprensible en términos mixtecos, como una narrativa sagrada consistente de fases diferenciadas. El "state-of-the-art" actual se basa en la sensibilidad a los conceptos mixtecos, incluyendo los de los herederos vivos, y a los problemas inherentes a los complejos problemas cronológicos de la historia mixteca.

\section{ACKNOWLEDGMENTS}

In preparing this article I owe a large debt to numerous Mixtecs and other colleagues, who have shared their time and knowledge with me. The Mixtec chronology was discussed in detail during the Second Workshop on Mixtec Codices, held at Austin in 1985. Equally valuable was the opportunity to participate in the Taller de Lectura de Códices Mixtecos, at Oaxaca in 1989, in which codices were studied and commented

\section{REFERENCES}

Acuña, René (editor)

1984 Relaciones Geográficas del siglo XVI: Antequera. 2 vols. Universidad Nacional Autónoma de México, Mexico.

Adelhofer, Otto

1974 Codex Vindobonensis Mexicanus 1. Akademische Druck- u. Verlagsanstalt, Graz.

Alexander, Ruth Mary

1980 Gramática Mixteca, Mixteco de Atatlahuca. Instituto Linguístico de Verano, México. upon by a number of experts, including several Mixtecs. I would especially like to thank Gabina Aurora Pérez for her active help and contributions, both in specific decipherments and in creating a critical view of this discipline in the wider context of the defense and development of indigenous cultures.
Alvarado, Francisco de

1963 (1593) Vocabulario en lengua mixteca, hecho por los padres de la orden de predicadores que residen en ella, y últimamente recopilado y acabado por el Padre... Vicario de Tamazulapa, de la misma orden. Instituto Nacional Indigenista-Instituto Nacional de Antropología e Historia, México.

Anders, Ferdinand

1967 Wort- und Sachregister zu Eduard Seler, Gesammelte Abhandlungen. Akademische Druck- u. Verlagsanstalt, Graz. 
Anders, Ferdinand, and Maarten Jansen

1988 Schrift und Buch im alten Mexiko. Akademische Druck-u. Verlagsanstalt, Graz.

Anders, Ferdinand, and Nancy Troike

1987 Codex Zouche-Nuttall, Akademische Druck- u. Verlagsanstalt, Graz.

APIBAC (Alianza de Profesionistas Indigenas Bilingües A.C.)

1980 Los Indigenas y su Politica Educativa. Los Remedios Ixmiquilpan.

Brioso y Candiani, Manuel

1910 Biografia del Sr. Manuel M. Gracida. Oaxaca.

Brotherston, Gordon

1983 The Year 3113 BC and the Fifth Sun of Mesoamerica: An Orthodox Reading of the Tepexic Annals (Codex Vindobonensis obverse). In Calendars in Mesoamerica and Peru: Native American Computations of Time, edited by Anthony F. Aveni and Gordon Brotherston, pp. 167-220. British Archaeological Reports, Oxford.

1985 The Sign Tepexic in its Textual Landscape. Ibero-Amerikanische Archiv N.F. XI(2):209-251.

Burgoa, Francisco de

1934 (1674) Geográfica Descripción. 2 vols. Publicaciones del Archivo General de la Nación 25-26. Talleres Gráficos de la Nación, México.

Burland, Cottie

1955 The Selden Roll. Ibero-Amerikanische Bibliothek zu Berlin, Berlin.

1965 Codex Egerton 2895. Akademische Druck- u. Verlagsanstalt, Graz.

Byland, Bruce E., and John M.D. Pohl

1989 In the Realm of 8 Deer. University of Oklahoma Press, Norman, in press.

Carriedo, Juan B.

1949 (1847) Estudios históricos y estadísticos del estado Oaxaqueño. Biblioteca de Autores y de Asuntos Oaxaqueños, Prólogo de Jorge Fernando Iturribarría, México.

Casas, Alejandro, Juan Luis Viveros, Esther Katz, and Javier Caballero 1987 Las plantas en la alimentación mixteca: Una aproximación etnobotánica. América Indígena XLVII(2):317-343.

Caso, Alfonso

1949 El Mapa de Teozacoalco. Cuadernos Americanos VIII(5): 145-181.

1960 Interpretación del Códice Bodley 2528. Sociedad Mexicana de Antropología, México.

1964 Interpretación del Códice Selden 3135. Sociedad Mexicana de Antropología, México.

1977-1979 Reyes y Reinos de la Mixteca. 2 vols. Fondo de Cultura Económica, México.

Caso, Alfonso, and Mary Elizabeth Smith

1966 Intrepretación del Códice Colombino/Interpretation of the Codex Colombino; Las glosas de Códice Colombino/The Glosses of Codex Colombino. Sociedad Mexicana de Antropología, México.

Castellanos, Abraham

1910 El Rey Iukano y los Hombres del Oriente. Leyenda indigena inspirada en los restos del "Códice Colombino." A. Carranza e Hijos, México.

Churchill, Ward (editor)

1988-1989 Critical Issues in Native North America. I.W.G.I.A Document 62. Copenhagen.

Clark, James Cooper

1912 The Story of "Eight Deer" in Codex Colombino. Taylor and Francis, London.

1938 The Mexican Manuscript Known as the Collection of Mendoza and Preserved in the Bodleian Library. Waterlow and Sons, London.

Codex

Becker: See Nowotny 1961b.

Bodley 2858: See Caso 1960.

Colombino: See Caso and Smith 1966

Egerton 2895: See Burland 1965.

Mendoza: See Clark 1938.

Nuttall: See Anders and Troike 1987.

Selden 3135 (A.2): See Caso 1964.

Sierra: See León 1982.

Vindobonensis: See Adelhofer 1974.
Corona Nuñez, José

1967 Antigüedades de México, basadas en la recopilación de Lord Kingsborough IV. Secretaría de Hacienda y Crédito Público, México.

Dahlgren de Jordán, Barbro

1954 La Mixteca: su cultura e historia prehispánicas. Imprenta Universitaria, México.

Dorson, R.M.

1955 The eclipse of solar mythology. Journal of American Folklore 68:393-416.

Dyk, Anne

1959 Mixteco Texts. Summer Institute of Linguistics, Norman.

Dyk, Ann, and Betty Stoudt

1973 Vocabulario mixteco de San Miguel el Grande. Instituto Linguístico de Verano, México.

Eschmann, Anncharlot

1976 Das religiose Geschichtsbild der Azteken. Indiana Beiheft 4. Berlin.

Fischer, Sibylle, and Michael Durr

1988 Cómo descifrar lo auténtico: Un ejemplo del indigenismo mixteco visto a través de sus fuentes. Ibero-Amerikanisches Archiv N.F. 14(2):149-172.

Flannery, Kent, and Joyce Marcus (editors)

1983 The Cloud People: Divergent Evolution of the Zapotec and Mixtec Civilizations. Academic Press, New York.

Furst, Jill L.

1977 The Tree Birth Tradition in the Mixteca, Mexico. Journal of Latin American Lore 3(2):183-226.

1978a Codex Vindobonensis Mexicanus I: A Commentary. Institute of Mesoamerican Studies, State University of New York, Albany.

1978b The Life and Times of 8 Wind "Flinted Eagle." Alcheringa 4(1):2-37

1978c The Year 1 Reed, Day 1 Alligator: A Mixtec Metaphor. Journal of Latin American Lore 4(1):93-128.

1982 Skeletonization in Mixtec Art: A Re-evaluation. In The Art and Iconography of Late Post-Classic Central Mexico, edited by Elizabeth H. Boone, pp. 207-225. Dumbarton Oaks, Washington, DC.

1986 The Lords of "Place of the Ascending Serpent:" Dynastic Succession on the Nuttall Obverse. In Symbol and Meaning Beyond the Closed Community. Essays in Mesoamerican Ideas, edited by Gary H. Gossen, pp. 57-68. Institute of Mesoamerican Studies, State University of New York, Albany.

1987 Mixtec Narrative Conventions and Variations: Problems in Defining Codex Nuttall as Mixtec. Latin American Indian Literatures Journal 3(1):9-26.

García, fray Gregorio

1981 (1607) Origen de los Indios del Nuevo Mundo. Fondo de Cultura Económica, México.

Garduño Cervantes, Julio

1983 El final del silencio: Documentos indigenas de México. La red de Jonas, México.

Gay, José Antonio

1978 (1881) Historia de Oaxaca. 2 vols. Gobiernoel Estado, Oaxaca

Gaxiola, Margarita, and Maarten Jansen (editors)

1978 Primera Mesa Redonda de Estudios Mixtecos. Instituto Nacional de Antropología e Historia, Oaxaca.

Glass, John B

1975 A Survey of Native Middle American Pictorial Manuscripts. In Handbook of Middle American Indians, Vol. 14: Guide to Eth nohistorical Sources, edited by Howard F. Cline, pp. 3-80. University of Texas Press, Austin.

Glass, John B., and Donald Robertson

1975 A Census of Native Middle American Pictorial Manuscripts. In Handbook of Middle American Indians, Vol. 14: Guide to Eth nohistorical Sources, edited by Howard F. Cline, pp. 81-252. University of Texas Press, Austin.

Gutiérrez Solana, Nelly

1987 Avances en los estudios sobre los Códices Mixtecos (1973-84). Anales del Instituto de Investigaciones Estéticas 58:35-45.

Herrera y Tordesillas, Antonio de

1947 Historia General de los Hechos de los Castellanos en las Islas y Tierra firme del Mar Océano 6. Academia de la Historia, Madrid. 
Hochleitner, Franz Joseph, and Ana Paula de Paula

1987 Princípios de uma determinação cronológia do codex Vindobonensis. In Novas Interpretações do Codex Vindobonensis, edited by Franz Joseph Hochleitner, Ana Paula de Paula, and Helmut Krumbach, pp. 5-46. Universidade Federal de Juiz de Fora, Juiz de Fora.

Hvidtveldt, Ärild

1959 Teotl and Ixiptlatli: Some Central Conceptions in Ancient Mexican Religion. Copenhagen.

Ibach, Thomas J.

1980 A Man Born of a Tree: A Mixtec Origin Myth. Tlalocan VIII: $243-247$

1981 The Temazcal and Humoral Medicine in Santa Cruz Mixtepec, Juxtlahuaca, Oaxaca, Mexico. Unpublished master's thesis, University of Tennessee, Knoxville.

Jansen, Maarten

1982a Viaje al Otro Mundo: La Tumba I de Zaachila. In Coloquio internacional Los indigenas de México en la época precolombina $y$ en la actualidad, edited by Maarten Jansen and Ted Leyenaar, pp. 87-118. Rijksmuseum voor Volkenkunde, Leiden.

1982b Huisi Tacu, estudio interpretativo de un libro mixteco antiguo: Codex Vindobonensis Mexicanus I. Centrum voor Studie en Documentatie van Latijns Amerika, Amsterdam.

1985 Las lenguas divinas del México precolonial. Boletín de Estudios Latinoamericanos y del Caribe 38:3-14.

1987 Dzavuindanda, Ita Andehui y Iukano, historia y leyenda mixteca. Boletín de Estudios Latinoamericanos y del Caribe 42:71-89.

1988a The Art of Writing in Ancient Mexico: An Ethno-iconological Perspective. Visible Religion VI:86-113.

1988b Dates, Deities and Dynasties, non-durational time in Mixtec historiography. In Continuity and Identity in Native America: Essays in Honor of Benedikt Hartmann, edited by Maarten Jansen, Peter van der Loo, and Roswitha Manning, pp. 156-192. E.J. Brill, Leiden.

1989 Nombres Históricos e Identidad Etnica en los Códices Mixtecos. European Review of Latin American and Caribbean Studies, Amsterdam, 47, pp. 65-87.

Jansen, Maarten, and Gabina Aurora Pérez

1983 The Ancient Mexican Astronomical Apparatus: An Iconographical criticism. Archaeoastronomy VI(1-4): 89-95.

1986 Iyadzehe Añute: Valor literario de los códices mixtecos. In Etnicidad y pluralismo cultural, La dinámica étnica en Oaxaca, edited by Alicia M. Barabas and Miguel A. Bartolomé, pp. 173-211. Instituto Nacional de Antropología e Historia, México.

Jiménez Moreno, Wigberto, and Salvador Mateos Higuera

1940 Códice de Yanhuitlan. Instituto Nacional de Antropología e Historia, México.

Josserand, J. Kathryn

1983 Mixtec Dialect History. Unpublished doctoral dissertation, Tulane University, New Orleans.

Josserand, J. Kathryn, Maarten Jansen, and Maria Angeles Romero

1984 Mixtec Dialectology: Inferences from Linguistics and Ethnohistory. In Essays in Otomanguean Culture History, edited by J. K. Josserand, Marcus Winter, and Nicholas Hopkins, pp. 141225. Vanderbilt University Publications in Anthropology 31, Nashville, TN.

Kohl, Karl-Heinz, and Marion Schmid (editors)

1982 Mythen der Neuen Welt: Zur Entdeckungsgeschichte Lateinamerikas. Frolich und Kaufmann, Berlin.

Kohler, Ulrich

1985 Olmeke und Jaguare, Zur Deutung von Mischwesen in der präklassischen Kunst Mesoamerikas. Anthropos 80:15-52.

Konig, Viola

1979 Inhaltiche Analyse und Interpretation von Codex Egerton. Beiträge zur mittelamerikanischen Volkerkunde XV, Hamburg.

1984 Der Lienzo Seler II und seine Stellung innerhalb der Coixtlahuaca Gruppe. Baessler Archiv N.F. 32(2):229-320.

Kreichgauer, Damian

1917 Die Astronomie der grossen Wiener Handschrift aus Mexiko. Sitzungsberichte der Akademie der Wissenschaften in Wien Phil. hist. Klasse 182(5).

Krumbach, Helmut

1982 Schwitzbaddarstellungen und deren Symbole in bilderhandschriften aus Mexiko. Zeitschrift fur Ethnologie 107(1):95-128.
La Cruz, Victor de

1983 Genealogía de los Gobernantes de Zaachila. Culturas Populares, Oaxaca.

Lehmann, Walter, and Ottokar Smital

1929 Codex Vindobonensis Mexic. 1. Verlag fur Nord u. Südamerika Kunstanstalt M. Jaffé, Vienna.

Lemaire, Ton

1986 De Indiaan in ons Bewustzijn. De ontmoeting van de Oude met de Nieuwe Wereld. Ambo, Baarn.

León, Nicolás

1982 (1933) Códice Sierra Editorial Innovación, México.

Lind, Michael

1979 Postclassic and Early Colonial Mixtec Houses in the Nochixtlan Valley, Oaxaca, Mexico. Vanderbilt University Publications in Anthropology 23, Nashville, TN.

Long, Richard C.E.

1926 The Zouche Codex. Journal of the Royal Anthropological Society 51:239-258.

Loo, Peter L. van der

1988 Old Models and New Tools in the Study of Mesoamerican Religion. In Continuity and Identity in Native America, edited by Maarten Jansen, Peter van der Loo, and Roswitha Manning, pp. 42-57. E.J. Brill, Leiden.

López Austin, Alfredo

1973 Hombre-Dios, religión y política en el mundo nahuatl. Universidad Nacional Autónoma de México, México.

1980 Cuerpo Humano e ideología, las concepciones de los antiquos nahuas. 2 vols. Universidad Nacional Autónoma de México, México.

López Ruiz, Mariano

1898 Estudio cronológico sobre la dinastía mixteca. Memorias de la Sociedad Científica "Antonio Alzate" XI:437-448.

Mak, Cornelia

1959 Mixtec Medical Beliefs and Practices. América Indígena XIX(2): 125-150.

Martínez Gracida, Manuel

1883 Colección de Cuadros sinópticos de los pueblos, haciendas y ranchos del Estado libre y soberano de Oaxaca. Gobierno del Estado de Oaxaca, Oaxaca.

Martínez Gracida, Manuel

1986 Los Indios Oaxaqueños y sus monumentos arqueológicos. Gobierno del Estado de Oaxaca, Oaxaca.

Martínez Gracida, Manuel, and Mariano López Ruiz

1906 Ita Andehui, leyenda mixteca. Oaxaca.

Melgarejo Vivanco, José Luis

1980 El Códice Vindobonensis. Instituto de Antropología, Universidad Veracruzana, Xalapa.

Mendez Aquino, Alejandro

1985 Historia de Tlaxiaco. Compañia Editorial Impresora y Distribuidora, México.

Monaghan, John D.

1990 The Great Pact with the Earth: Contemporary Mixtec Mythol ogy and the Vienna Codex. American Antiquity, in press.

Nicholson, H.B.

1978 The Deity 9 Wind "Ehecatl-Quetzalcoatl" in the Mixteca Pictorials. Journal of Latin American Lore 4(1):61-92.

Nowotny, Karl Anton

1948 Erlauterungen zum Codex Vindobonensis (Vorderseite). Archiv fur Volkerkunde III:156-200.

1960 Mexikanische Kostbarkeiten aus Kunstkammern der Renaissance im Museum fur Volkerkunde in Wien und in der Nationalbibliothek Wien. Vienna.

1961a Tlacuilolli: die mexikanischen Bilderhandschriften: Stil und Inhalt, mit einem Katalog der Codex Borgia Gruppe. Monumenta Americana, Verlag Gebr. Mann, Berlin.

1961b Codices Becker I/II. Akademische Druck- u. Verlagsanstalt, Graz.

Ortíz López, Pedro C.

1982 Análisis morfosintáctico del constituyente nominal del mixteco de Santa María Yucuhiti Oaxaca. Etnolinguística. S.E.P-Instituto Nacional Indígenista, México.

Parmenter, Ross

1982 Four Lienzos of the Coixtlahuaca Valley. Dumbarton Oaks, Washington, DC. 
1988 Cracking the Codices: The Contribution of Zelia Nuttall. Manuscript in possession of author.

Pastor, Rodolfo

1987 Campesino y Reformas: La Mixteca. 1700-1856. El Colegio de México, México.

Paulat Legorreta, Jorge

1969 Una leyenda Mixteca. Anales del Instituto Nacional de AnPaw

tropología e Historia, séptima época, I:181-184.

1951 Algunas observaciones acerca de la religión de los mixtecos guerrerenses. Revista Mexicana de Estudios Antropológicos XII: $147-164$.

Pérez, Gabina Aurora

1988 Sain Sau, introducción al mixteco de Chalcatongo. In Continuity and Identity in native America, essays in honor of Benedikt Hartmann, edited by Maarten Jansen, Peter van der Loo, and Roswitha Manning, pp. 132-155. E.J. Brill, Leiden.

Pohl, John

1984 The Earth Lords: Politics and Symbolism of the Mixtec Codices. Unpublished doctoral dissertation, University of California, Los Angeles.

Rabin, Emily.

1979 The War of Heaven in Codices Zouche-Nuttall and Bodley: A Preliminary Study. Actas del XLII Congreso Internacional de Americanistas (Paris) VII:173-182.

1981 Chronology of the Mixtec Historical Codices: An Overview. Paper presented at the Annual Meeting American Society for Ethnohistory, Colorado Springs.

1982 Confluence in Zapotec and Mixtec Ethnohistories: The 1560 Genealogy of Macuilxochitl. Papers in Anthropology (Norman) 23(2):359-368.

Ramsey, James R.

1982 An examination of Mixtec Iconography. In Aspects of the Mixteca-Puebla Style and Mixtec and Central Mexican Culture in Southern Mesoamerica, edited by Doris Stone, pp. 32-42. Middle American Research Institute Occasional Paper 4, Tulane University, New Orleans, LA.

Reyes, Antonio de los

1976 (1593) Arte en Lengua Mixteca. Vanderbilt University Publications in Anthropology 14, Nashville, TN.

Robertson, Donald

1982a A preliminary Note on the Codex Tulane. In Coloquio internacional los indigenas de México en la época precolombina y en la actualidad, edited by Maarten Jansen and Ted Leyenaar, pp. 223 231. Rijksmuseum voor Volkenkunde, Leiden.

1982b Some Comments on Mixtec Historical Manuscripts. In Aspects of the Mixteca-Puebla Style and Mixtec and Central Mexican Culture in Southern Mesoamerica, edited by Doris Stone, pp. 15-26. Middle American Research Institute Occasional Paper 4. Tulane University, New Orleans, LA.

Rock, Fritz

1935 Ein altindianisches Bilderbuch. Frohes Schaffen XI:193-204. Wien.

Romero Frizzi, Ma. de los Angeles

1976 Indice del archivo del juzgado de Tepozcolula. Instituto $\mathrm{Na}$ cional de Antropología e Historica, Oaxaca.

1985 Economía y vida de los españoles en la Mixteca Alta, 15191720. Unpublished doctoral dissertation, Universidad Ibero-Americana, México.

Scheicher, Elisabeth

1979 Die Kunst- und Wunderkammern der Habsburger. Molden Edition, Vienna/Munich/Zurich.

Schultze Jena, Leonhard

1938 Indiana III: Bei den Azteken, Mixteken und Tlapaneken der Sierra Madre del Sur von Mexiko. Verlag Gustav Fischer, Jena.

Séjourné, Laurette

1981 El Pensamiento Náhautl Cifrado por los Calendarios. Siglo Veintiuno, Mexico.

Seler, Eduard

1960-1961 (1902-1923) Gesammelte Abhandlungen zur Amerikanischen Sprach- und Altertumskunde. 5 vols. Akademische Drucku. Verlagsanstalt, Graz.
Seler-Sachs, Caecilie

1900 Auf alten Wegen in Mexiko und Guatemala. Dietrich Reimer, Berlin.

Silva Fuentes, Fidelia

1988 Poesía y poetas de Nochixtlan. Colección Siete Venado, Casa de la Cultura, Oaxaca.

Smith, Mary Elizabeth

1973a Picture Writing from Ancient Southern Mexico: Mixtec Place Signs and Maps. University of Oklahoma Press, Norman.

$1973 \mathrm{~b}$ The relationship between Mixtec manuscipt painting and the Mixtec language. In Meso-american Writing Sytems, edited by Elizabeth P. Benson, pp. 47-98. Dumbarton Oaks, Washington, DC.

1979 Codex Becker II: A Manuscript from the Mixteca Baja? Archiv fur Volkerkunde 33:29-43.

1983 Codex Selden: A Manuscript from the Valley of Nochixtlan. In The Cloud People: Divergent Evolution of the Zapotec and Mixtec Civilizations, edited by Kent V. Flannery and Joyce Marcus, pp. 248-255. Academic Press, New York.

1988 It Doesn't Amount to a Hill of Beans: The Frijol Motif in Mixtec Place Signs. In Smoke and Mist: Mesoamerican Studies in Memory of Thelma D. Sullivan, edited by J. Kathryn Josserand and Karen Dakin, pp. 696-710. British Archaeological Reports International Series 402 , Oxford.

Spinden, Herbert

1935 Indian Manuscripts of Southern Mexico. Annual Report of the Smithsonian Institution, 1933:429-451.

1940 Diffusion of Maya Astronomy. In The Maya and their Neighbors: Essays on Middle American Anthropology and Archaeology, edited by Clarence L. Hay, Ralph L. Linton, Samuel K. Lothrop, Harry L. Shapiro, and George C. Vaillant, pp. 162-178. AppletonCentury, New York.

Spores, Ronald

1967 The Mixtec Kings and Their People. University of Oklahoma Press, Norman.

1972 An Archaeological Settlement Survey of the Nochixtlan Valley, Oaxaca. Vanderbilt University Publications in Anthropology 1, Nashvillè, TN.

1974a Stratigraphic Excavations in the Nochixtlan Valley, Oaxaca, Mexico. Vanderbilt University Publications in Anthropology 11, Nashville, TN

1974b Marital Alliance in the Political Integration of Mixtec Kingdoms. American Anthropologist 76:297-311.

1984 The Mixtecs in Ancient and Colonial Times. University of Oklahoma Press, Norman.

Toorians, Lauran

1983 Some Light in the dark century of Codex Vindobonensis Mexicanus 1. Codices Manuscripti IX:26-29.

1984 Codex Vindobonensis Mexicanus 1, its History Completed. Codices Manuscripti X:87-97.

Torquemada, Juan de

1975-1979 Monarquia Indiana. 6 vols. Universidad Nacional Autónoma de México, México.

Troike, Nancy

1974 The Codex Colombino-Becker. Unpublished doctoral dissertation, University of London.

1978 Fundamental Changes in the Interpretation of the Mixtec Codices. American Antiquity 43(4):553-568.

1979 Preliminary Notes on Stylistic Patterns in the Codex Bodley. Actas del XLII Congreso Internacional de Americanistas VII:183-192.

1980 The Identification of Individuals in the Codex ColombinoBecker. Tlalocan VIII:397-418.

1982a Studying Style in the Mixtec Codices: An Analysis of Variations in the Codex Colombino-Becker. In Pre-Columbian Art History, edited by Alana Cordy-Collins, pp. 119-151. Peek Publications, Palo Alto, CA.

1982b The interpretation of Postures and Gestures in the Mixtec Codices. In The Art and Iconography of Late Post-Classic Central Mexico, edited by Elizabeth H. Boone, pp. 175-206. Dumbarton Oaks, Washington, DC. 